Volume 11

Issue 3 Global Approaches to Atrocity

Prevention: Theory, Practice, and the State of

Article 16 the Field

3-2018

\title{
Book Review: Politics of Innocence: Hutu Identity, Conflict and Camp Life
}

Andrea Purdekova

University of Bath

Follow this and additional works at: https://digitalcommons.usf.edu/gsp

\section{Recommended Citation}

Purdekova, Andrea (2018) "Book Review: Politics of Innocence: Hutu Identity, Conflict and Camp Life," Genocide Studies and Prevention: An International Journal: Vol. 11: Iss. 3: 137-138.

DOI:

http://doi.org/10.5038/1911-9933.11.3.1511

Available at: https://digitalcommons.usf.edu/gsp/vol11/iss3/16

This Book Review is brought to you for free and open access by the Open Access Journals at Digital Commons @ University of South Florida. It has been accepted for inclusion in Genocide Studies and Prevention: An International Journal by an authorized editor of Digital Commons @ University of South Florida. For more information, please contact digitalcommons@usf.edu. 
Book Review: Politics of Innocence: Hutu Identity, Conflict and Camp Life

Andrea Purdeková

University of Bath

Bath, United Kingdom

Politics of Innocence: Hutu Identity, Conflict and Camp Life

Simon Turner

Oxford and New York, Berghahn Books, 2010

185 Pages; Price \$120.00 Hardback

Reviewed by Andrea Purdeková

University of Bath, United Kingdom

With the recent migration crisis in the global North and the unrelenting pressure on host countries in the global South where the vast majority of refugees continue to reside, Simon Turner's is a book that should be read widely. Turner's careful ethnographic study of the micropolitics unfolding in Lukole refugee camp for Burundian refugees in Tanzania remains one of the few books offering an intimate portrait of daily life and conflicted politics of a refugee camp. By combining the bird's eye perspective with that of a close-up street view, Turner diverges from the removed global economy analyses or the overly technical language of humanitarian reports by offering a perspective that is both empirically rich and theoretically engaged.

Turner's aim is to explore not how history creates conflict but how conflict creates histories and how this relationship manifests in the space of the camp. As such, the book sits within an emerging body of literature that challenges a one-sided Agambenian characterization of camp inhabitants as "bare life" suspended in an exceptional state of limbo and an apolitical space of exclusion. Research in conflict-affected areas such as Western Sahara or Eastern DRC has shown that refugee camps are instead saturated with refugee politics, at extreme ends acting as quasistates or "practice polities." While Turner doesn't deny that liminality and exceptionality do define the refugee camp, his picture is fundamentally one of ambiguity and he skillfully foregrounds the interplay of "powers" in Lukole - between Tanzanian authorities and humanitarian agencies on the one hand, and the refugees as they maneuver the space of the camp and construct their own subjectivities. At the same time as they link the space of the camp with social and moral decay, with experiences of status loss and emasculation ("UNHCR is a better husband"1 being fed by "food distribution"2) Lukole's inhabitants also strategically take advantage of new opportunities. Chapter five excels in tracing concrete stories of such "liminal experts."

In fact, the book is at its best when it discusses such paradoxes and ambiguities of camp governance. Chapter three is especially strong on this, foregrounding the tensions between real disempowerment faced by the refugees due to the restrictions and prescriptions (down to the form and style of their blindé) ${ }^{3}$ imposed by the camp commandant and the humanitarian agencies, and on the other hand the "empowerment" in form of participation promoted by the same agencies, ${ }^{4}$ or the fact that indeed camp life did offer empowerment of sorts to its inhabitants by shaking up old hierarchies and opening up new opportunities.

Turner's careful study certainly succeeds in breaking down some of the pervasive stereotypes surrounding the figure of the refugee and the space of the camp. The book challenges the notion that the space of the camp is uniformly disempowering in chapter four by showing how the politics of gender plays out differently for men and women, and across status lines. The book also deconstructs the image of the refugee as a passive victim by foregrounding the politics of guilt and the loss of innocence among the Hutu, who in the 1990s can no longer claim the mantle of

\footnotetext{
${ }^{1}$ Simon Turner, Politics of Innocence: Hutu Identity, Conflict and Camp Life (New York and Oxford: Berghahn, 2010), 66.

${ }^{2}$ Ibid., 68.

${ }^{3}$ Ibid., 45.

${ }^{4}$ Ibid., 52.

Andrea Purdeková, "Book Review: Politics of Innocence: Hutu Identity, Conflict and Camp Life" Genocide Studies and Prevention 11, 3 (2018): 137-138. @2018 Genocide Studies and Prevention. 
"innocence" due to their own imbrications in violence inside Burundi. Through analysis of the political parties operating in the camp in chapter six, the book breaks down the image of refugee as an apolitical figure of a human in need. Turner's distinct contribution here is his portrayal of the camp as a political arena where different parties and ideologies compete for allegiance and the ability to shape the historical narrative. Chapter six is a fascinating reflection on rumor as a currency mediating this political competition.

Turner's Politics of Innocence presents a key contribution to the study of camps and encampment, in Africa and more widely. It builds on and extends the seminal work by Liisa Malkki ${ }^{5}$ who, incidentally also working with Burundian refugees in Tanzania a decade prior, linked the space of the camp to the production of strongly ethnonationalist historical narratives, narratives likely to perpetuate rather than diffuse violence. But Malkki left camp politics aside, making it seem that the narratives she gathered arose in a political vacuum. By contrast, Turner foregrounds the fundamental ambiguity of the camp as both a space depoliticized through humanitarian quasi-governance and hyperpoliticized through competition among political parties. Through the struggle between the CNDD and Palipehutu, Turner persuasively shows that production of history depends on power struggles in the space of the camp. The narratives of Hutu ethnic and moral purity that Malkki collected could simply not arise again. The histories that emerged during Turner's time in the camp were not only conditioned by intra-Hutu political competition but also constrained by the loss of the Hutu victim position through their own imbrication in violence in the early 1990s and onwards.

Future work is needed to extend and systematize some of the insights that Turner offers in his book. The experiences of women in the camp are notably missing. Accent is also primarily on "big men" and the liminal experts benefitting from the opportunities of the camp rather than those "sitting around" or bemoaning their loss of status. Going forward, more historical depth and a comparative perspective would be useful in order to map out the historical transformation in the experiences of Burundian encampment, the changing operation of political parties in exile and across the different camps, and the circulation of refugees between the national space, the space of the camp and other exilic spaces. Only such more systematic political exploration could deliver the answer to the key question that Turner and Malkki open up to view: What is the relation between the space of the camp, the production of history and the nature of nationalism that emerges in exile? And how do these tie to the dynamics of ongoing conflict? If it is not Turner's intention to provide such broader-ranging investigation, it is certainly the merit of the book that it inspires us to ask novel and more pointed questions about encamped experiences and their relation to both conflict and peace building in a region that has seem some of the most entrenched and large-scale violence of recent decades. The recent mass outflow of Burundians out of the country marks a new chapter in the regional conflict-displacement nexus and further underscores the continued and pressing relevance of the queries tackled in Turner's Politics of Innocence.

${ }^{5}$ Lisa H. Malkki, Purity and Exile: Violence, Memory, and National Cosmology Among Hutu Refugees in Tanzania (Chicago: Chicago University Press, 1995). 